\title{
New promoters for the molybdenum hexacarbonyl- mediated Pauson-Khand reaction
}

\author{
Alexandre F. Trindade, Željko Petrovski,* and Carlos A. M. Afonso* \\ CQFM, Departamento de Engenharia Química e Biológica, Instituto Superior Técnico, \\ Complexo I, Av. Rovisco Pais, 1049-001 Lisboa, Portugal \\ E-mail:zeljko@,ist.utl.pt and carlosafonso@ist.utl.pt
}

\begin{abstract}
A systematic study of new additives for the stoichiometric molybdenum hexacarbonyl- mediated Pauson-Khand reaction resulted in the discovery of several active compounds such as tetrasubstituted thioureas, ester and amide derivatives of phosphoric acid, quaternary ammonium bromides and phosphine oxides. Tributylphosphine oxide (TBPO) was the most efficient additive providing PK products in moderate to good yields. Some experimental evidences were found which support a non-oxidative $\mathrm{Mo}(\mathrm{CO})_{6}$ activation by TBPO.
\end{abstract}

Keywords: Pauson-Khand, molybdenum hexacarbonyl, additives, phosphine oxide, thiourea, cyclopentenone

\section{Introduction}

Since its discovery ${ }^{1}$ in the early 1970 s, the Pauson-Khand reaction (PKR) - originally mediated by cobalt and later found to proceed in the presence of other metal complexes (Rh, Ir, Ti, Zr, Fe, $\mathrm{Ru}, \mathrm{Cr}, \mathrm{Mo}, \mathrm{W}, \mathrm{Ni}$, etc.) — has received great attention due to its potential application in complex molecules synthesis. ${ }^{2}$ The reaction can proceed in the presence of a stoichiometric amount of metal carbonyl (source of carbon monoxide) or catalytically under a $\mathrm{CO}$ gas atmosphere, or alternatively with compounds that can form such metal carbonyls. Most of the references related to the PKR that have appeared recently in the literature reflect an increasing interest for the development of novel transition metal catalysts and methods ${ }^{3-9}$ for PKR and their application in organic synthesis. ${ }^{10-12}$

The first example of stoichiometric molybdenum mediated PKR was reported in 1992 by Hanaoka et al. The authors found that bis-(cyclopentadienyl)dimolybdenum-alkyne complexes (isoelectronic with hexacarbonyldicobalt-alkyne complexes) are also suitable reactants for intraand inter- molecular PKR. ${ }^{13}$ However, only one year later, when Jeong et al. disclosed the $\mathrm{Mo}(\mathrm{CO})_{6} / \mathrm{DMSO}$ system, the molybdenum-mediated PKR provided a robust methodology for 
enyne substrates (Scheme 1). ${ }^{14}$ For this transformation, high temperatures $\left(100^{\circ} \mathrm{C}\right)$ and a large excess of DMSO are required to promote the $\mathrm{CO}$ decomplexation steps, providing vacant sites for the coordination of both alkyne and alkene to molybdenum.

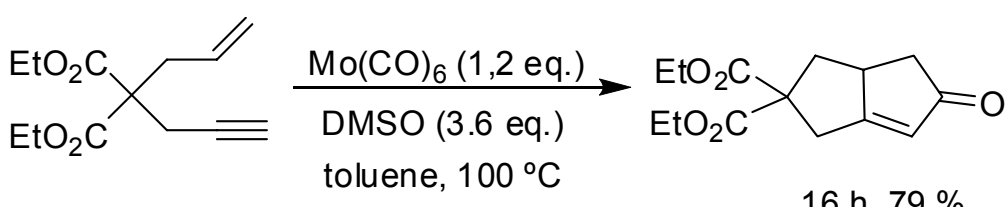

\section{Scheme 1}

Compared with other transition metal promoters of $\mathrm{PKR}, \mathrm{Mo}(\mathrm{CO})_{6}$ presents many advantages. The reactant is stable to air and moisture, is affordable and available, has low toxicity, and its by-products generated during the reaction can be removed by filtration through a pad of silica gel. Additionally, an interesting regioselectivity towards the internal double bond of allene- containing substrates has been observed. ${ }^{15}$ Furthermore, the $\mathrm{Mo}(\mathrm{CO})_{6} / \mathrm{DMSO}$ system proved to be more sensitive in diyne-diene substrate tandem PKR than the cobalt-mediated process, providing tetracyclic systems in higher yields. ${ }^{18,19}$ All the described advantages make the $\mathrm{Mo}(\mathrm{CO})_{6} / \mathrm{DMSO}$ system an important tool for organic synthesis, especially in cases where other PK systems failed to produce the desired transformation. ${ }^{11,15,16}$

Chiral alkynyl allenes were used in molybdenum- mediated PKR in an attempt to transfer chirality to the products. ${ }^{20}$ It was reasoned that the axial chirality of a 1,3-disubstituted allene could be transferred to the stereocenter formed at the ring fusion of the $\alpha$-alkylidene cyclopentenone via a selective addition of the metal-alkyne complex to one face of the allene. Molybdenum hexacarbonyl was chosen to undergo this transformation instead of the Co- and $\mathrm{Zr}$ mediated processes, since the first provides the desired regioselectivity in PKR using allenic substrates. Some examples of hetero- PKR with molybdenum promotion were also described. ${ }^{17}$ Recently, the first successful application was described of catalytic $\mathrm{Mo}(\mathrm{CO})_{6}$ under $\mathrm{CO}$ atmosphere (1 atm.) with 1,6- allenynes, which provided PK products in good yields. ${ }^{8}$

Hetero-bimetallic Co-Mo alkyne complexes obtained by replacing a $\mathrm{Co}(\mathrm{CO})_{3}$ group in alkyne- $\mathrm{Co}_{2}(\mathrm{CO})_{6}$ complexes with an isoelectronic $\mathrm{CpMo}(\mathrm{CO})_{2}$ fragment were also found to be active in PK- type reactions and later applied in stereoselective PKR. ${ }^{6,21}$ Some ligand labile molybdenum species of the general formula of $\mathrm{Mo}(\mathrm{CO})_{\mathrm{n}} \mathrm{L}_{6-\mathrm{n}}(n=5-3)$; $\mathrm{L}=\mathrm{DMF}$, THF, $\left.\mathrm{CH}_{3} \mathrm{CN}\right)$, prepared from $\mathrm{Mo}(\mathrm{CO})_{6}$, were used in the stoichiometric PKR of 1,6- and 1,7-enynes and 1-ethynyl-2-allenylbenzenes. Such species provided the conditions for PKR occur at lower temperatures $\left(0-40^{\circ} \mathrm{C}\right)$ for a wide variety of substituents and functional groups including alkenes having an electron withdrawing substituent. ${ }^{7,9}$

As mentioned before, a wide range of compounds has been employed and well studied as additives in cobalt carbonyl- mediated PKR such as tertiary amine oxides, phosphines, phosphine oxides, DMSO, hard Lewis bases, alkyl- and phosphine sulfides and others as promoters of 
initial CO decomplexation. ${ }^{2}$ It is usually assumed that complexation of the substrate to one cobalt atom takes place via a dissociative mechanism involving initial loss of CO. This process is almost certainly reversible but it also allows substrate coordination to the metal's vacant site. In the amine $\mathrm{N}$-oxide promoted reaction, $\mathrm{CO}_{2}$ should be liberated in the first step, and the process then becomes irreversible. ${ }^{22}$

In the case of molybdenum-mediated PKR no experimental evidence has been given in the literature that could explain this initial mechanistic step, as far as we are aware. In fact, in the work of Jeong et al. neither process (oxidative and non- oxidative) was ruled out as a mechanistic possibility. ${ }^{14}$ In contrast to cobalt-mediated PKR, no general study has been completed of the molybdenum-promoted PKR, and the lack of data of the influence of various additives prompted us to explore this chemistry.

\section{Results and Discussion}

\section{Additive screening}

Initially the goal was to find new promoters in molybdenum-mediated PKR. For this purpose, a carrousel reaction station apparatus was used to test around 70 different compounds (see Figure 2 in the Experimental Section). In each vial a sample of enyne 1 (10 mg), $\mathrm{Mo}(\mathrm{CO})_{6}(15 \mathrm{mg}, 1.2$ eq.) and an additive (3.6 eq.) were dissolved in dry toluene $(2 \mathrm{~mL})$ under argon atmosphere. The reaction was run at $100{ }^{\circ} \mathrm{C}$ and monitored by TLC (Table 1). In this screening, one vial was always used to run a standard reaction where DMSO was used as the additive. 
Table 1. Effect of various additives on molybdenum- mediated PKR

\begin{tabular}{|c|c|c|c|c|c|c|c|c|}
\hline Entry & Additive & Res. $^{\mathrm{a}}$ & Entry & Additive & Res. $^{\text {a }}$ & Entry & Additive & Res. $^{\mathrm{a}}$ \\
\hline 1 & none & +- & 24 & TMSCN & - & 47 & $n-\mathrm{Bu}_{4} \mathrm{NF} \cdot 3 \mathrm{H}_{2} \mathrm{O}$ & +- \\
\hline 2 & $\mathrm{MeCN}$ & +- & 25 & EtCN (as solvent) & +- & 48 & $\mathrm{Me}_{4} \mathrm{NCl}$ & - \\
\hline 3 & $\left(\mathrm{Me}_{2} \mathrm{~N}\right)_{2} \mathrm{CS}$ & + & 26 & dicyclopentadiene & - & 49 & $\mathrm{PhSOMe}$ & +- \\
\hline 4 & DMF & 0 & 27 & $\mathrm{SnCl}_{4}$ & - & 50 & TTMPP & + \\
\hline 5 & $\mathrm{Ph}_{3} \mathrm{P}$ & +- & 28 & $\begin{array}{c}\mathrm{SnCl}_{4}+ \\
\left(\mathrm{Me}_{2} \mathrm{~N}\right)_{2} \mathrm{CS}\end{array}$ & - & 51 & Thiophenol & - \\
\hline 6 & HMPA & + & 29 & $\mathrm{SOCl}_{2}$ & - & 52 & $n-\mathrm{Bu}_{3} \mathrm{PO}$ & + \\
\hline 7 & BSA & - & 30 & $n-\mathrm{Bu}_{3} \mathrm{SnCl}$ & - & 53 & EtSLi & 0 \\
\hline 8 & ferrocene & +- & 31 & $\begin{array}{c}n-\mathrm{Bu}_{3} \mathrm{SnCl}+ \\
\left(\mathrm{Me}_{2} \mathrm{~N}\right)_{2} \mathrm{CS}\end{array}$ & +- & 54 & $\mathrm{Ph}_{3} \mathrm{PO}$ & + \\
\hline 9 & $\left(\mathrm{Me}_{2} \mathrm{NCS}\right)_{2} \mathrm{~S}_{2}$ & 0 & 32 & $\mathrm{HC}(\mathrm{OEt})_{3}$ & - & 55 & Thiourea & 0 \\
\hline 10 & EtSSEt & +- & 33 & Dioxane & 0 & 56 & $\mathrm{CH}_{2}=\mathrm{CHSiMe}_{2} \mathrm{Cl}$ & - \\
\hline 11 & $\mathrm{PhSeSePh}$ & +- & 34 & $\mathrm{I}_{2}$ & - & 57 & $\mathrm{Na}_{2} \mathrm{SO}_{4}$ & +- \\
\hline 12 & $\mathrm{Et}_{3} \mathrm{PO}$ & + & 35 & $n-\mathrm{Bu}_{4} \mathrm{NBr}$ & + & 58 & $(\mathrm{PhCOO})_{2}$ & 0 \\
\hline 13 & $N$-methylimidazole & +- & 36 & $n-\mathrm{Bu}_{4} \mathrm{NI}$ & +- & 59 & $(\mathrm{EtO})_{3} \mathrm{PO}$ & + \\
\hline 14 & Fluorene & +- & 37 & $\mathrm{Et}_{3} \mathrm{~N}$ & 0 & 60 & $\mathrm{LiBr}$ & - \\
\hline 15 & 2,6-dimethylpyridine & +- & 38 & NMO & +- & 61 & $\left(\mathrm{CF}_{3} \mathrm{SO}_{2}\right)_{2} \mathrm{NLi}$ & 0 \\
\hline 16 & pyridine & + & 39 & $\mathrm{CoCl}_{2} \cdot \mathrm{H}_{2} \mathrm{O}$ & - & 62 & $\mathrm{PhSO}_{3} \mathrm{Na}$ & 0 \\
\hline 17 & $\mathrm{HCSNMe}_{2}$ & + & 40 & DCC & +- & 63 & $\left(\mathrm{Me}_{2} \mathrm{~N}\right)_{2} \mathrm{CS}$ & 0 \\
\hline 18 & $\mathrm{HCOOBu}$ & 0 & 41 & $\mathrm{Me}_{3} \mathrm{Al}$ & +- & 64 & $\begin{array}{c}\text { N-methyl- } \\
\text { thiourea }\end{array}$ & 0 \\
\hline 19 & $\mathrm{Me}_{2} \mathrm{COMe}_{2}$ & +- & 42 & $\mathrm{EtCN}$ & +- & 65 & $\mathrm{TiCl}_{4}$ & - \\
\hline 20 & $\mathrm{Ph}_{3} \mathrm{PS}$ & - & 43 & $n-\mathrm{Bu}_{3} \mathrm{SnH}$ & - & 66 & $\mathrm{Me}_{2} \mathrm{NCSCl}$ & - \\
\hline 21 & thiophene & 0 & 44 & $\left(\mathrm{Me}_{2} \mathrm{~N}\right)_{3} \mathrm{P}$ & 0 & 67 & Phenol & 0 \\
\hline 22 & $\mathrm{PhNO}_{2}$ & - & 45 & $n-\mathrm{C}_{16} \mathrm{H}_{33} \mathrm{NMe}_{3} \mathrm{Br}$ & + & 68 & $(\mathrm{EtO})_{3} \mathrm{P}$ & 0 \\
\hline 23 & $\mathrm{Et}_{3} \mathrm{~B}$ & +- & 46 & $n-\mathrm{C}_{16} \mathrm{H}_{33} \mathrm{NMe}_{3} \mathrm{OTs}$ & + & 69 & $\left(\mathrm{Me}_{3} \mathrm{Si}\right)_{2} \mathrm{NH}$ & 0 \\
\hline
\end{tabular}

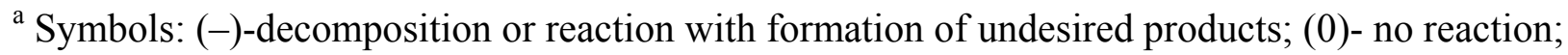
$(+-)$ - some product formation or very dirty reaction; $(+)$ - complete and clean PKR. Abbreviations: $\mathrm{N}, \mathrm{O}$-bis-(trimethylsilyl acetamide (BSA); hexamethylphosphoramide (HMPA); Tris-(2,4,6-trimethoxyphenyl)phosphine (TTMPP); N,N'-Dicyclohexylcarbodiimide (DCC).

Interestingly, when no additive was used, the PKR became too slow since the PK product 2 was only detected after a long induction period (Table 1, Entry 1). After 20 hours the starting material was still present and clear signs of decomposition were observed. 
In addition to some previous studies ${ }^{14}$ we found that, under the same conditions, oxidant additives did not provide any PK product $\mathbf{2}$ such as DMSO gives. With dibenzoyl peroxide no reactivity was observed, and the iodine induced decomposition of the starting material (Table 1, Entries 34 and 58). In the case of NMO, the use of diphenyl diselenide and diethyl disulphide (Table 1, Entries 10, 11, 38) gave some PK product 2 but the reaction was too slow, giving nonselective or dirty reactions.

Some labile ligands, such as DMF, acetonitrile, butyl formate, or propionitrile were also tested as additives (Table 1, Entries 2, 4, 18 and 42). Unlike DMF and butyl formate, all nitriles promoted PKR although the reaction was slower than in DMSO. When propionitrile was used as solvent some product formation occurred, but the reaction became even slower. We believe that under these conditions the labile ligand can substitute carbonyls, forming a $\mathrm{Mo}(\mathrm{CO})_{3}(\mathrm{EtCN})_{3}$ complex, but the large excess of propionitrile probably inhibits substrate coordination to the metal. A similar problem was observed when no activity of $\mathrm{Mo}(\mathrm{CO})_{3}(\mathrm{DMF})_{3}$ was detected in solvents such as DMF and acetonitrile. ${ }^{7}$

Because the in situ-generated $\mathrm{Bu}_{4} \mathrm{~N}\left[(\mathrm{CO})_{5} \mathrm{WF}\right]$ and $\mathrm{Bu}_{4} \mathrm{~N}\left[(\mathrm{CO})_{5} \mathrm{CrF}\right]$ complexes were active in $\mathrm{PKR},{ }^{23}$ we also explored the activity of quaternary ammonium salts in molybdenum- mediated PKR (Table 1, Entries 35-36 and 45-48). Tetrabutylammonium bromide proved to be the best choice, and the starting material was fully consumed after 4 hours. Surprisingly, the inorganic salts like $\mathrm{Na}_{2} \mathrm{SO}_{4}$ also showed some activity, although the reaction was slow and very dirty (Table 1, Entry 57).

Several additives that were shown to have positive effects in cobalt- mediated PKR (hard Lewis bases such as NMO and dioxane, $\mathrm{Ph}_{3} \mathrm{PS}{ }^{25}$ or triethylamine) failed to give molybdenumpromoted PKR. Pyridine and 2,6-dimethylpyridine show some beneficial effect, but were not sufficiently attractive for further studies - considering their toxicity, also (Table 1 Entries 15, 16). The reaction was almost always completely inhibited or retarded in the presence of any phosphine, phosphite and phenol (Table 1, Entries 5, 67, 68). Surprisingly, with methyl phenyl sulfoxide the reaction was not finished after 20 hours and was dirty (Table 1, entry 49).

The additives that seemed to provide smooth and complete PK reaction with fast consumption of the starting material and clean formation of the PK product $\mathbf{2}$ were studied on a preparative scale (Table 2). The purity of the PKR products isolated was confirmed by ${ }^{1} \mathrm{H}-\mathrm{NMR}$ spectroscopy.

\section{Quantitative evaluation}

Gratifyingly, amide and ester derivates of phosphoric acid, aryl- and alkyl- phosphine oxides, and thioureas proved to be useful additives in PKR and were explored on preparative scale (Table 2).

The positive effect of thioureas in cobalt ${ }^{4}$ - and palladium ${ }^{5}$ - mediated PKR, and the known ability of such ligands to substitute for the carbonyls in $\mathrm{Mo}(\mathrm{CO})_{6}{ }^{\prime}$ providing $^{26}$ (TMTU)Mo(CO) ${ }_{5}$, prompted us to explore them first. Of all the thioureas tested, tetramethylthiourea (TMTU) proved to be the most reactive, affording 2 with $54 \%$ yield in 16 hours (Table 2, Entry 4 s 
Entries 5-8). Apparently, only tetra-substituted thioureas can be used as promoters since thiourea, methylthiourea and 1,3- dimethylthiourea (Table 2, Entries 6-8) failed to promote PKR. During purification by preparative chromatography it was found that TMTU caused some contamination problems, since it co-runs with some PK products. Several types of work-up tested failed to remove TMTU from the reaction mixture before the final purification. Alternatively to overcome this limitation, a less polar thiourea was synthesized (Table 2, Entry 5 ), but unfortunately was less effective than TMTU, probably due to steric hindrance. Of the ester and amide derivatives of phosphoric acid disclosed HMPA proved to be more efficient than triethyl phosphate (Table 2, Entries 9 and 10).

Table 2. Effect of selected additives on the PK reaction for substrate model 1 using $\mathrm{Mo}(\mathrm{CO})_{6}{ }^{\mathrm{a}}$

\begin{tabular}{|c|c|c|c|c|c|c|c|}
\hline & $\mathrm{O}_{2} \mathrm{C}^{-}$ & 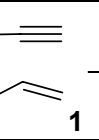 & $\begin{array}{l}\mathrm{Mo}(\mathrm{CO})_{6} 1 \\
\text { additive } 3 \\
\text { toluene, } 1\end{array}$ & & $\begin{array}{l}\mathrm{MeO}_{2} \mathrm{C} \\
\mathrm{MeO}_{2} \mathrm{C}\end{array}$ & & \\
\hline Entry & Additive & $\begin{array}{l}\text { Time } \\
\text { (h) }\end{array}$ & $\begin{array}{c}\text { Yield }^{\mathrm{b}} \\
(\%) \\
\end{array}$ & Entry & Additive & $\begin{array}{l}\text { Time } \\
(\mathrm{h})\end{array}$ & $\begin{array}{c}\text { Yield }^{\mathrm{b}} \\
(\%)\end{array}$ \\
\hline 1 & DMSO & 16 & 84 & 11 & Ethyldiphenylphosphine oxide & 16 & 44 \\
\hline 2 & DMSO & 2 & 67 & 12 & MOM-diphenylphosphine oxide & 16 & 60 \\
\hline 3 & $\begin{array}{l}\text { Tetrabutylammonium } \\
\text { bromide }\end{array}$ & $4 \mathrm{~h}$ & 17 & 13 & Triphenylphosphine oxide & 16 & 40 \\
\hline 4 & TMTU & 16 & 54 & 14 & Triphenylphosphine oxide & 2 & 37 \\
\hline 5 & $\begin{array}{l}\text { 1,1-Dihexyl-3,3- } \\
\text { dimethylthiourea }\end{array}$ & 23 & 37 & 15 & Tributylphosphine oxide & 16 & 65 \\
\hline 6 & Thiourea & 18 & Traces & 16 & Tributylphosphine oxide & 2 & 63 \\
\hline 7 & Methylthiourea & 18 & Traces & 17 & Triethylphosphine oxide & 16 & 63 \\
\hline 8 & 1,3-Dimethylthiourea & 18 & Traces & 18 & Triethylphosphine oxide & 2 & 64 \\
\hline 9 & HMPA & 16 & 53 & 19 & Diphenylphosphine oxide & 2 & 0 \\
\hline 10 & Triethyl phosphate & 16 & 37 & 20 & Trimethylphosphine oxide & 2 & 57 \\
\hline
\end{tabular}

${ }^{a}$ Substrate $(0.29 \mathrm{mmol}), \mathrm{Mo}(\mathrm{CO})_{6}(1.2$ eq.), additive (3.6 eq.), co-additive (3.6 eq. if applied) toluene, $100{ }^{\circ} \mathrm{C}$ under argon. ${ }^{b}$ Yield after purification by preparative chromatography.

Although the yields from the $\mathrm{Mo}(\mathrm{CO})_{6} / \mathrm{DMSO}$ method (Table 2, Entry 1) were never surpassed, trialkylphosphine oxides were the most active additives tested and allowed an interesting reduction in the reaction time. When applied, all the starting material was consumed in just $2 \mathrm{~h}$ and the yield of the PK product was always above 60\%. DMSO also provides similar yield after 2 hours - Table 2, Entry 2. Increasing the reaction time did not improve the reaction yield (Table 2, Entries 13 vs 14, 15 vs 16, and 17 vs 18). Substitution of alkyl by aryl groups resulted in lower yields and increased reaction time (Table 2, Entries 11, 15, 17 vs Entry 13, and Entry 16, 18, $20 v s$ Entry 14). Curiously, when methoxymethyldiphenylphosphine oxide was used some improvement was observed compared with the other aromatic phosphine oxides. It 
was speculated that the ether moiety present in this ligand could also coordinate to molybdenum, enhancing CO substitution by a chelating effect (Table 2, Entry $11 v s$ Entry 12). Interestingly, diphenylphosphine oxide failed to give any PKR product (Table 2, Entry 19). The beneficial effect present in this type of ligands was not surprising, in spite the fact that they did not show high activity in cobalt- mediated PKR. Like TMTU, triphenylphosphine oxide is also known to react with $\mathrm{Mo}(\mathrm{CO})_{6}$ providing quite stable di- and tri- substitution complexes. ${ }^{28}$

Although TLC showed selective formation of the PK product with complete consumption of starting material, the isolated yield was not quantitative. A traditional PKR using $\mathrm{Mo}(\mathrm{CO})_{6} / \mathrm{DMSO}$ system always finishes with the precipitation of dark bluish solid ${ }^{14}-$ an obvious proof that the carbonyl complex was destroyed and molybdenum was at least partially oxidized. In the new $\mathrm{Mo}(\mathrm{CO})_{6} / \mathrm{R}_{3} \mathrm{PO}$ system no precipitation occurred, and the yellowish-brown reaction mixture was applied directly to a preparative chromatography plate.

We speculated that the known stability ${ }^{28}$ of the phosphine oxide complexes with $\mathrm{Mo}(\mathrm{CO})_{6}$ may help to trap some PK product to molybdenum. So, we decided to add another additive that could, at the end of the reaction, promote the product's decomplexation. Triethylamine was the first choice. Gratifyingly, in some cases its presence improved the reaction yield by $20 \%$ (Table 3, Entry $3 v s$ Entry 4). During the screening we already observed that after 2 hours triethylamine alone does not promote PK with any considerable conversion (Table 3, Entry 7).

Several readily available tertiary amines were also tested as co-additives. However, only triethylamine improved the isolated yield. In fact, DABCO (Table 3, Entry 8) and ethyl-diisopropylamine (Table 3, Entry 10) gave deterioration in the yield, while pyridine (Table 3, Entry 9) blocked the PKR during the first 2 hours, probably by poisoning the molybdenum.

The methodology was extended to several other PK substrates, and although the positive effect of triethylamine was not always observed, phosphine oxides proved to be efficient additives for this reaction (Table 3, Entries 12-21). Electron- poor compounds such as 7 are usually demanding substrates for the PK reaction, so it was no surprise that no PK product was isolated (Table 3, Entries 16, 17).

Table 3. Scope of substrates for the PK reaction using $\mathrm{Mo}(\mathrm{CO})_{6}$ promoted by phosphine oxides additives $^{\mathrm{a}}$

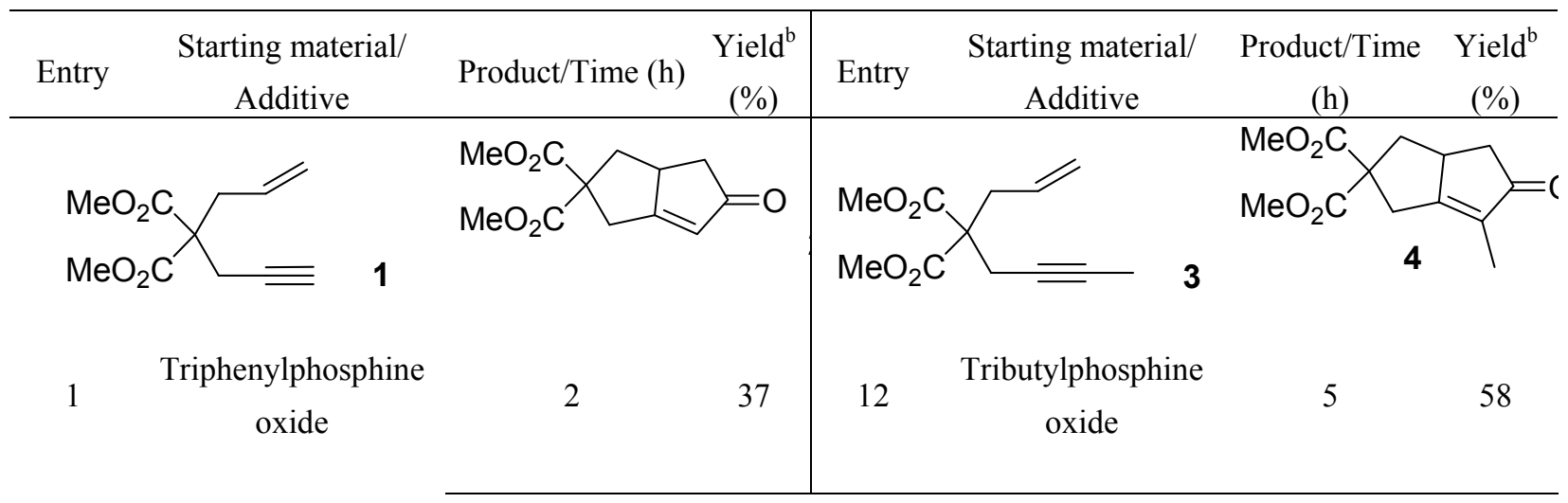




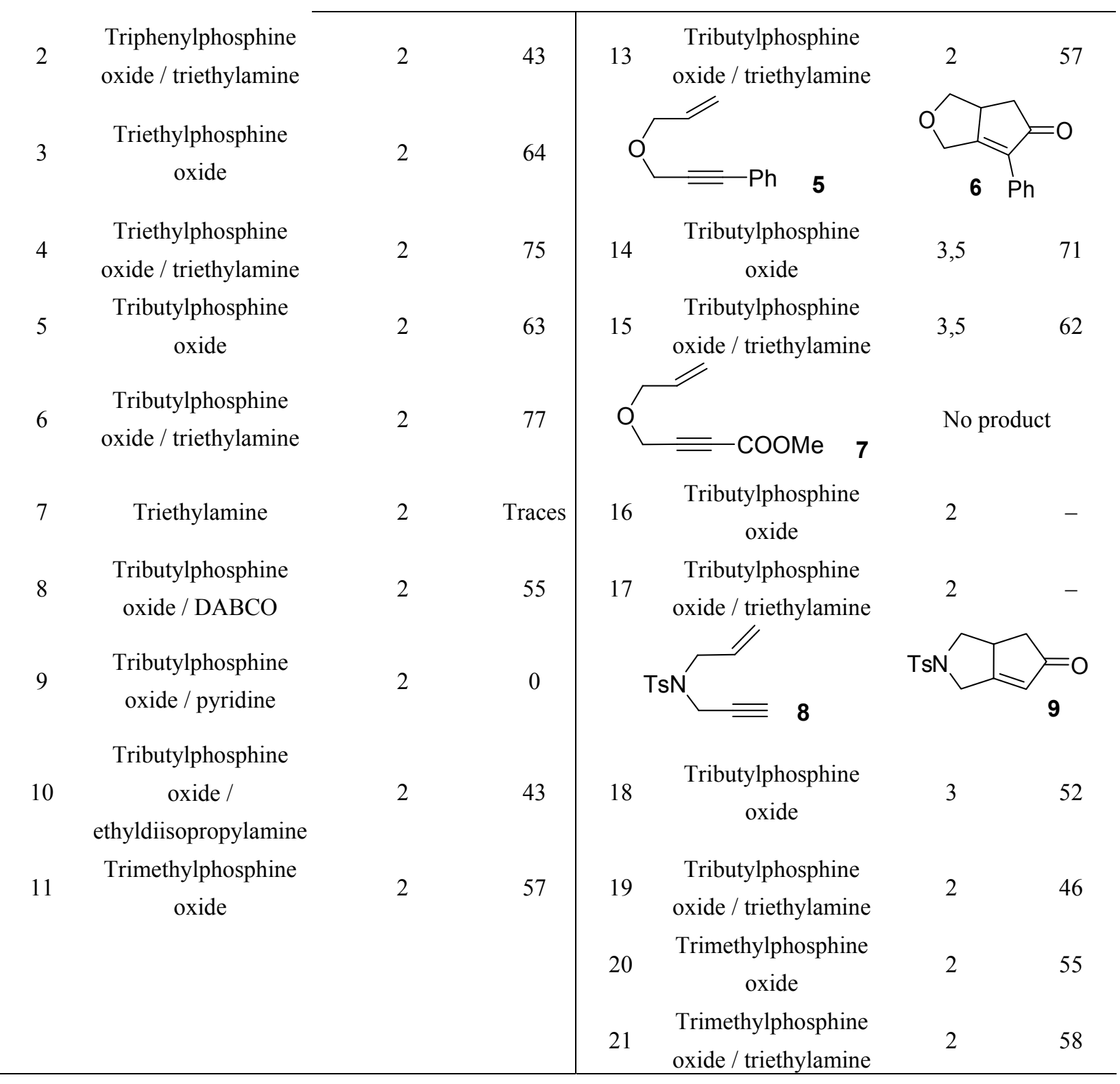

${ }^{a}$ Substrate $(0.29 \mathrm{mmol}), \mathrm{Mo}(\mathrm{CO})_{6}(1.2$ eq.), additive (3.6 eq.), co-additive (3.6 eq. if applied) toluene, $100{ }^{\circ} \mathrm{C}$ under Argon. ${ }^{b}$ Isolated yield after purification by preparative chromatography.

These results made us suspect that the base could generate an acetylide from terminal alkynes that might coordinate more easily to the metal in a $\eta^{1}$-manner. Once bound to the metal the acetylide could be protonated, and the reaction take a normal mechanistic course. ${ }^{14}$ Alternatively, if the acetylide is carbonylated before protonation, the reaction could follow a different mechanistic pathway. This alternative mechanism was suggested for explanation of novel zirconium catalyzed PKR. ${ }^{29}$ This behavior is known, as the mediation of molybdenum carbene generated from terminal alkyne and $\mathrm{Et}_{3} \mathrm{NMo}(\mathrm{CO})_{5}$ has been proved in the cyclization of alkynols and epoxyalkynols. ${ }^{30}$ 
Recently, Gibson et al. demonstrated that N-heterocyclic carbenes ("NHC") are suitable ligands for $\mathrm{Co}(\mathrm{CO})_{8^{-}}$mediated $\mathrm{PKR}^{36}$ Several complexes bearing one "NHC" ligand were prepared, characterized and tested. We therefore studied the effect of this class of ligands in $\mathrm{Mo}(\mathrm{CO})_{6^{-}}$mediated PKR. It was observed that the carbene could coordinate to molybdenum, promoting PKR at lower temperatures $\left(80^{\circ} \mathrm{C}\right.$ ), although the yields were not high (Scheme 2). When the temperature was lowered to $60{ }^{\circ} \mathrm{C}$, the reaction was slower and less selective, since another product was formed together with PK product. These results demonstrate the strong affinity and capacity of $\mathrm{NHC}$ to coordinate to molybdenum and enhance $\mathrm{CO}$ substitution. To our knowledge, this is the first example of a PKR promoted by $\mathrm{Mo}(\mathrm{CO})_{6}$ occurring at temperatures below $100{ }^{\circ} \mathrm{C}$.
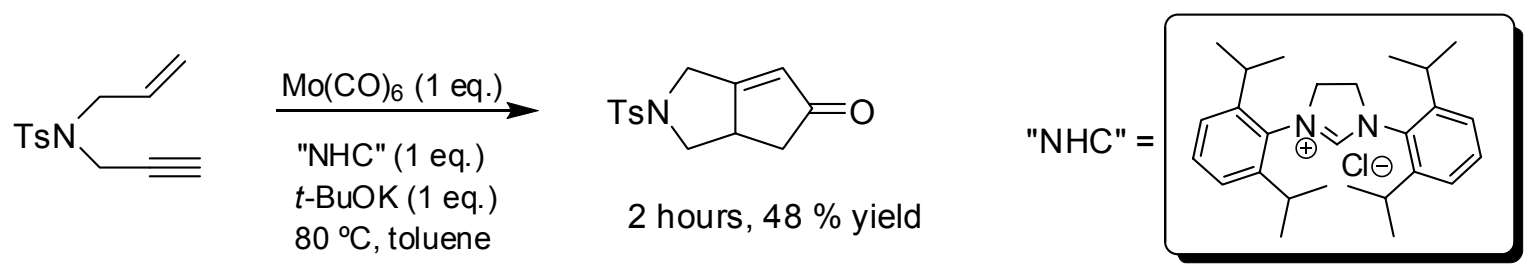

\section{Scheme 2}

We made a final attempt to realize this cyclization with catalytic $\mathrm{Mo}(\mathrm{CO})_{6} /$ additive under a balloon of $\mathrm{CO}$, but only starting material was detected. The dissociation of the $\mathrm{CO}$ from the molybdenum was obviously inhibited by the presence of carbon monoxide, which retarded the generation of a vacant coordination site and of the reaction, as recently described. ${ }^{12}$ Further exploration of "NHC" and phosphine oxide ligands will be made to achieve possible applications in asymmetric- and/or catalytic PKR.

\section{Mechanistic notes}

It is not surprising, based on thermodynamic considerations, that phosphine oxides do not make $\mathrm{CO}_{2}$, unlike amine oxides in cobalt- mediated PKR, but only substitute carbonyl ligands on a metal atom by a weaker, more easily replaceable ligands. ${ }^{22,27}$ This assumption was confirmed by ${ }^{31} \mathrm{P}$ - NMR, where either no free (Figure 1, spectrum A $v s$ spectrum D) or coordinated tributylphosphine (Figure 1, spectrum C vs spectrum D) was detected in a crude reaction sample (Figure 1). 

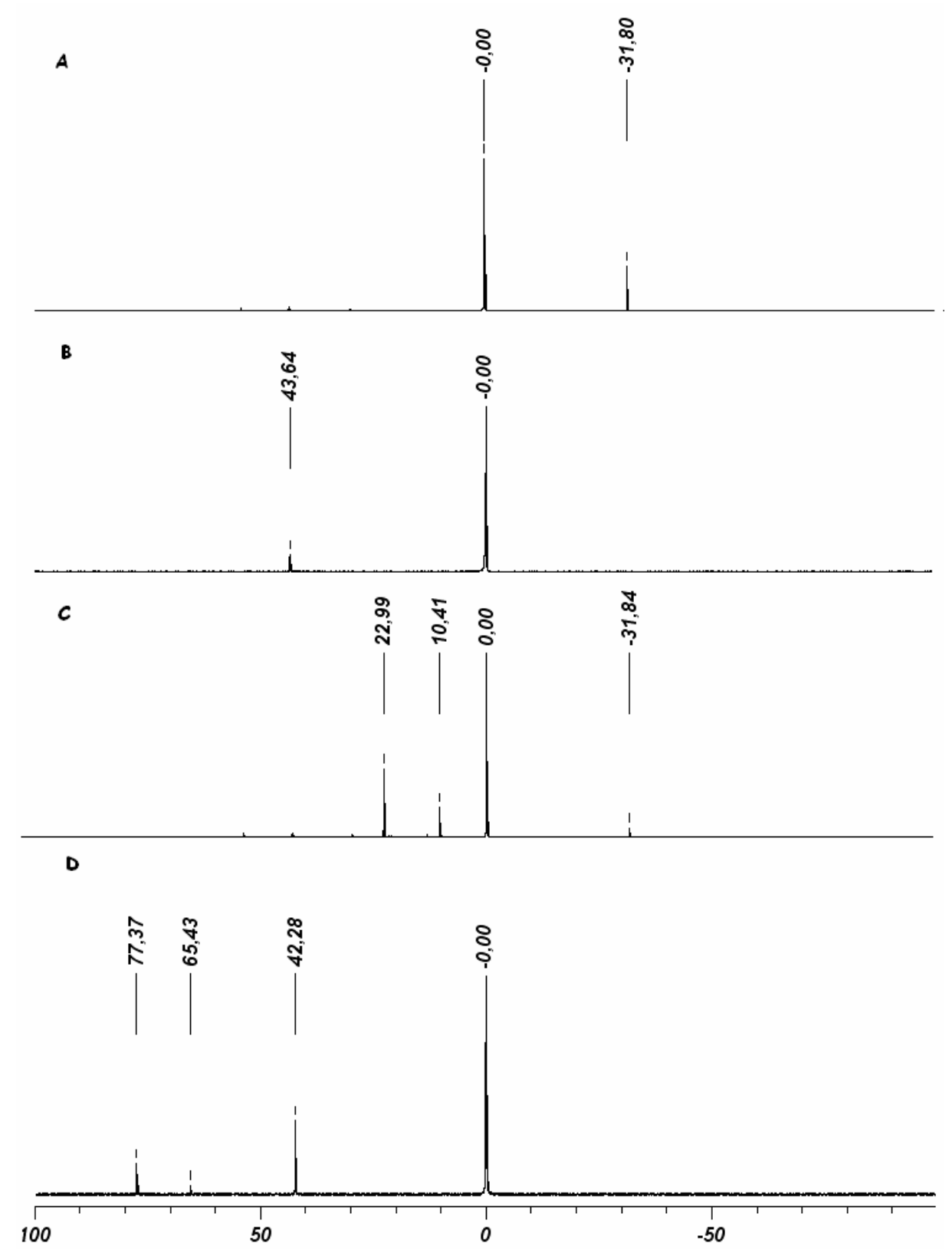

Figure 1. (a) ${ }^{31} \mathrm{P}$ - NMR spectra of tributylphosphine in toluene- $\mathrm{d}_{8}$; (b) ${ }^{31} \mathrm{P}-\mathrm{NMR}$ spectra of tributylphosphine oxide in toluene- $\mathrm{d}_{8} ;$; (c) Reaction of tributylphosphine with $\mathrm{Mo}(\mathrm{CO})_{6}$ in toluene after $10 \mathrm{~min}$. in toluene- $\mathrm{d}_{8}$; (d) ${ }^{31} \mathrm{P}$ - NMR spectrum of a crude sample of Table 3 , entry 18 , reaction in toluene- $\mathrm{d}_{8}$

The peaks at 77.37 and $65.43 \mathrm{ppm}$ should correspond to tributylphosphine oxide coordinated to molybdenum. However, to the best of our knowledge the only pure phosphine oxide molybdenum carbonyl complexes (with no other group attached to the metal) that are reported in literature are complexes of triphenylphosphine oxide. Unfortunately they were not characterized by ${ }^{31} \mathrm{P}-\mathrm{NMR} .{ }^{28}$ Since triphenylphospine oxide is not appropriate additive (Table 3 , entry 3 ) we 
attempted to prepare molybdenum-tributylphosphine oxide but this approach failed. The collected data made us conclude that carbonyl substitution by ligand probably plays an important part in $\mathrm{Mo}(\mathrm{CO})_{6}$ - mediated $\mathrm{PKR}$, not only by providing a coordination site for the substrate (after ligand dissociation) but also by stabilizing the molybdenum complex changing the reactivity which is not possible in case of oxidative pathway.

\section{Conclusions}

A systematic search for additives in $\mathrm{Mo}(\mathrm{CO})_{6}$ - mediated PKR revealed a new class of efficient promoters. The use of phosphine oxides provides a robust method to synthesize useful bicyclic enones with a considerable reduction in the reaction time and, in the case of NHC, also a reduction in the reaction temperature, which may open perspectives for new asymmetric ligands for PKR. In some cases, the addition of triethylamine as co-additive also improves the reaction yield. It was demonstrated that the phosphine oxide ligand does not promote PKR via oxidation.

\section{Experimental Section}

General Procedures. All reagents were purchased from Aldrich, except molybdenum hexacarbonyl which was from Fluka; all were used without further purification. THF, toluene and dichloromethane were distilled from $\mathrm{CaH}_{2} ;$ methanol was dried and distilled from magnesium. All reactions involving dried solvents were carried out in flame- or oven-dried glass under an argon atmosphere, and monitored by TLC on Merck silica gel $60 \mathrm{~F}_{254}$ sheets. All Pauson-Khand products were purified by preparative chromatography with Merck Silica gel 60 $\mathrm{F}_{254}$. NMR spectra were recorded on a Bruker AMX-300 spectrometer, with residual undeuterated solvent $\left(\mathrm{CDCl}_{3}\right.$ and $\left.\mathrm{C}_{6} \mathrm{D}_{5} \mathrm{CD}_{3}\right)$ or TMS as internal reference. The following compounds were prepared as reported previously in the literature: dimethyl 2-(2-propenyl)-2-(2propynyl)propan-1,3-dioate 1, ${ }^{31}$ dimethyl 1-methyl-6-hepten-1-yne-4,4-dicarboxylate 3, ${ }^{31,32} 1$-(3(allyloxy)prop-1-ynyl)benzene 5, ${ }^{33}$ methyl 4-(allyloxy)-2-butynoate $7,{ }^{34} \mathrm{~N}$-(2-propenyl)-N-(2propynyl)-4-methylbenzenesulfonamide 9 . $^{35}$

1,1-Dihexyl-3,3-dimethylthiourea. To a $25 \mathrm{~mL}$ round-bottomed flask was added $N, N$ dimethylthiocarbamoyl chloride (197 mg, $1.6 \mathrm{mmol})$ dissolved in $10 \mathrm{~mL}$ of dried dichloromethane. To this solution was added dihexylamine $(0.38 \mathrm{~mL}, 1.6 \mathrm{mmol})$ followed by triethylamine $(0.25 \mathrm{~mL}, 1.7 \mathrm{mmol})$, and heated under reflux. After $24 \mathrm{~h}$ the solvent was evaporated, and the residue purified by column chromatography. 1,1-Dihexyl-3,3dimethylthiourea was isolated as a colorless oil in $28 \%$ yield $(120 \mathrm{mg}) ;{ }^{1} \mathrm{H}-\mathrm{NMR}\left(\mathrm{CDCl}_{3}, 300\right.$ $\left.\mathrm{MHz}, 25^{\circ} \mathrm{C}\right): \delta 3.43(\mathrm{t}, J=7.5 \mathrm{~Hz}, 4 \mathrm{H}), 3.04(\mathrm{~s}, 6 \mathrm{H}), 1.54(\mathrm{bs}, 4 \mathrm{H}), 1.25(\mathrm{bs}, 12 \mathrm{H}), 0.85(\mathrm{t}, \mathrm{J}=6$ $\mathrm{Hz}, 6 \mathrm{H}) \mathrm{ppm} ;{ }^{13} \mathrm{C}-\mathrm{NMR}\left(\mathrm{CDCl}_{3}, 75 \mathrm{MHz}, 25^{\circ} \mathrm{C}\right): \delta 52.4,43.2,31.5,27.6,26.6,22.5,14.0 \mathrm{ppm}$; 
IR (neat): 2954, 2929, 2856, 1687, 1495, 1462, 1400, 1361, 259, 1173, 1117, 1057, 877, 725, $665 \mathrm{~cm}^{-1}$, HRMS (EI+): Calc: $m / z$ 272.228621, found: $\mathrm{m} / z 272.228020$

\section{Experimental procedure and apparatus used in the screening (Table 1)}

A carousel reaction station apparatus (Figure 2, left) was used to test around 70 different compounds. In each vial a sample of enyne 1 (10 mg), $\mathrm{Mo}(\mathrm{CO})_{6}(15 \mathrm{mg} ; 1.2$ eq.) and an additive (3.6 eq.) were dissolved in dry toluene $(2 \mathrm{~mL})$. The reaction was run at $100{ }^{\circ} \mathrm{C}$ and monitored by TLC (Table 1, representative TLC are presented in Figure 2, on the right). In this screening, one vial was always used to run a standard reaction where DMSO was used as additive.
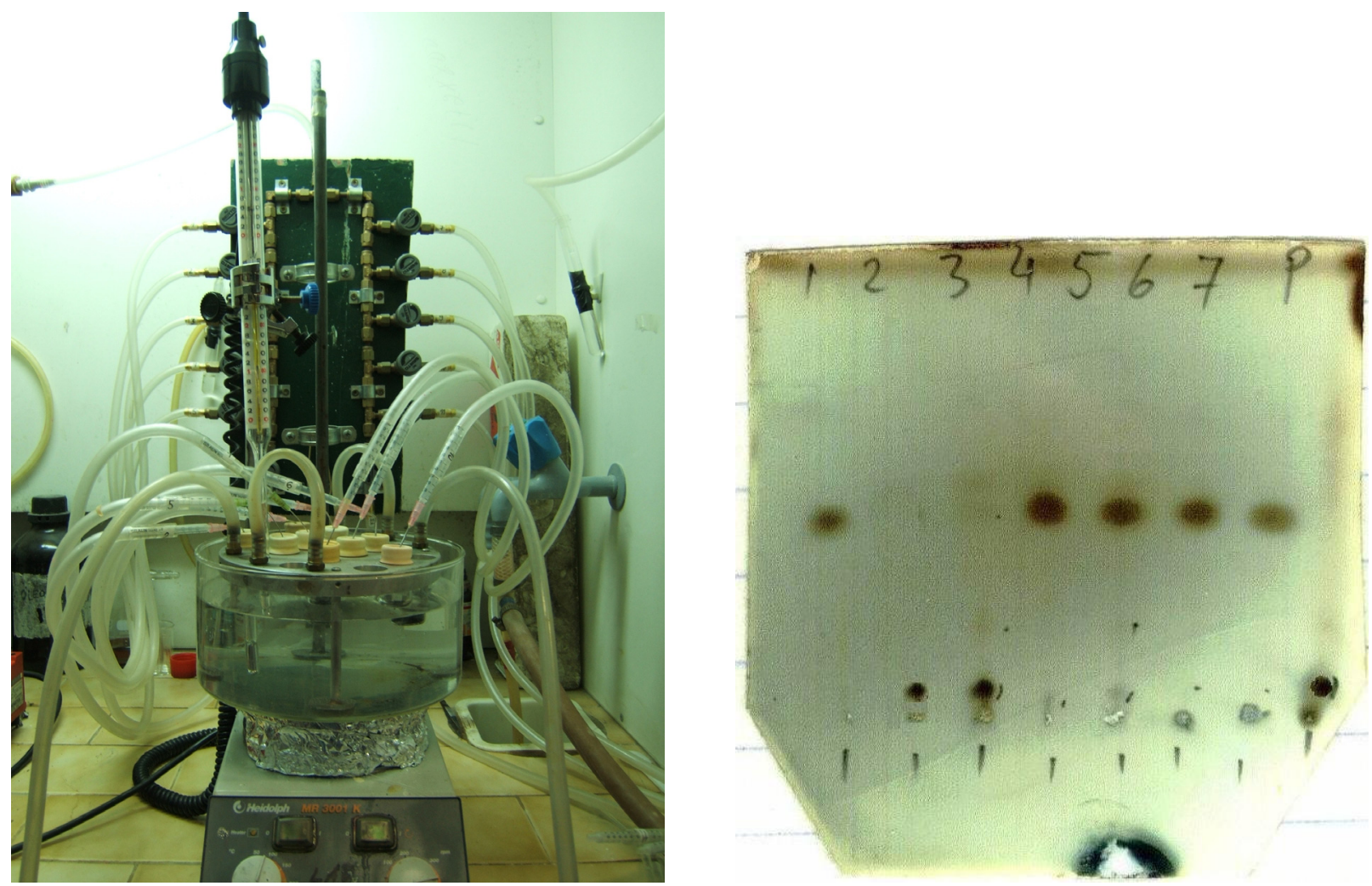

Figure 2. Home-made carrousel reaction station apparatus (left) and typical TLC observed from the screening experiments (right) (1 - no additive; 2 - DMSO; 3 - triphenylphosphine oxide; 4 thiophene; 5 - phenol; $\left.6-(\mathrm{EtO})_{3} \mathrm{P} ; 7-\left(\mathrm{Me}_{3} \mathrm{Si}\right)_{2} \mathrm{NH}\right)$ and $\mathrm{P}-\mathrm{PK}$ product $)$.

\section{General procedure for Pauson-Khand reactions (Table 2 and 3)}

To a $25 \mathrm{~mL}$ two-necked round bottomed flask were added enyne 1 (61 mg, $0.29 \mathrm{mmol})$, molybdenum hexacarbonyl (95 mg, $0.36 \mathrm{mmol}, 1.2$ eq.) and additive(s) (1.0 mmol, $3.6 \mathrm{eq})$. Dried toluene $(3 \mathrm{~mL})$ was added and the reaction carried out at $100{ }^{\circ} \mathrm{C}$. When all starting material was consumed (TLC) the reaction mixture was concentrated, the concentrate directly applied to silica, and the clean PK product isolated by thin-layer chromatography (eluent: diethyl ether). The purity of the product was confirmed by ${ }^{1} \mathrm{H}-\mathrm{NMR}$ spectroscopy and comparison with reported spectral data. 
When the "NHC" was used as ligand the procedure was equivalent to the one described, since in this case it was necessary to generate the carbene ligand before the PKR. In a well dried and purged Schlenk tube, an equimolar mixture of imidazolidinium salt and potassium $t$-butoxide were reacted in THF at $60^{\circ} \mathrm{C}$ for $15 \mathrm{~min}$. Next, the THF was evaporated to dryness, and the remaining reactants were added, followed by toluene. The reaction was continued for $2 \mathrm{~h}$ at 80 ${ }^{\circ} \mathrm{C}$. When all starting material was consumed (TLC) the mixture was concentrated, the concentrate directly applied to silica, and the clean PK product isolated by TLC (eluent: diethyl ether). The purity of the product was confirmed by ${ }^{1} \mathrm{H}-\mathrm{NMR}$ and comparison with reported spectral data.

( \pm )-5,5-Dicarbomethoxy-3a,4,5,6-tetrahydro-2(3H)-pentalenone (2). ${ }^{31}$ Isolated as a colorless oil, in $64 \%$ yield (Table 3, Entry 3). ${ }^{1} \mathrm{H}$ NMR $\left(\mathrm{CDCl}_{3}, 300 \mathrm{MHz}\right): \delta 5.88(\mathrm{~d}, J=1.2 \mathrm{~Hz}, 1 \mathrm{H})$, $3.75(\mathrm{~s}, 3 \mathrm{H}), 3.71(\mathrm{~s}, 3 \mathrm{H}), 3.24(\mathrm{~d}, J=11.1 \mathrm{~Hz}, 1 \mathrm{H}), 3.06(\mathrm{~m}, 1 \mathrm{H}), 2.77(\mathrm{dd}, J=12.6 \mathrm{~Hz}$ and $J=$ $7.5 \mathrm{~Hz}, 1 \mathrm{H}), 2.58$ (dd, $J=18 \mathrm{~Hz}, 6.6 \mathrm{~Hz}, 1 \mathrm{H}), 2.08$ (dd, $J=18 \mathrm{~Hz}, 3.3 \mathrm{~Hz}, 1 \mathrm{H}), 1.70$ (t, $J=12.6$ $\mathrm{Hz}, 1 \mathrm{H}) \mathrm{ppm}$.

Dimethyl ester of ( \pm )-6-methyl-5-oxo-3,3a,4,5-tetrahydro-1 $H$-pentalene-2,2-dicarboxylic acid (4). ${ }^{31,32}$ A pale yellow oil; $57 \%$ yield (Table 3, Entry 13$) .{ }^{1} \mathrm{H} \mathrm{NMR}\left(\mathrm{CDCl}_{3}, 300 \mathrm{MHz}\right): \delta$ $3.76(\mathrm{~s}, 3 \mathrm{H}), 3.72(\mathrm{~s}, 3 \mathrm{H}), 3.18(\mathrm{bd}, J=6 \mathrm{~Hz}, 1 \mathrm{H}), 2.93(\mathrm{~m}, 1 \mathrm{H}), 2.76(\mathrm{dd}, J=12.6 \mathrm{~Hz}$ and $J=$ $7.5 \mathrm{~Hz}, 1 \mathrm{H}), 2.60(\mathrm{dd}, J=18 \mathrm{~Hz}$ and $6.3 \mathrm{~Hz}, 1 \mathrm{H}), 2.04(\mathrm{dd}, J=18 \mathrm{~Hz}$ and $2.7 \mathrm{~Hz}, 1 \mathrm{H}), 1.68$ (s, $3 \mathrm{H}), 1.62(\mathrm{t}, J=12.6 \mathrm{~Hz}, 1 \mathrm{H}) \mathrm{ppm}$.

( \pm )-2-Phenyl-7-oxabicyclo[3.3.0]oct-1-en-3-one (6). ${ }^{33}$ Isolated as a colorless oil, in $71 \%$ yield (Table 3, Entry 14); ${ }^{1} \mathrm{H}$ NMR $\left(\mathrm{CDCl}_{3}, 300 \mathrm{MHz}\right): \delta 7.19-7.46(\mathrm{~m}, 5 \mathrm{H}), 4.87(\mathrm{~d}, J=16.5 \mathrm{~Hz}$, $1 \mathrm{H}), 4.51(\mathrm{~d}, J=16.5 \mathrm{~Hz}, 1 \mathrm{H}), 4.30$ (t, $J=7.2 \mathrm{~Hz}, 1 \mathrm{H}), 3.12-3.26(\mathrm{~m}, 2 \mathrm{H}), 2.80$ (dd, $J=17.7 \mathrm{~Hz}$ and $J=6 \mathrm{~Hz}, 1 \mathrm{H}), 2.27(\mathrm{dd}, J=17.7 \mathrm{~Hz}$ and $J=6 \mathrm{~Hz}, 1 \mathrm{H})$.

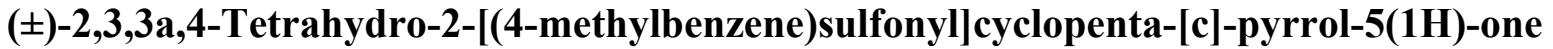

(10). ${ }^{35}$ isolated as a pale yellow powder, in $52 \%$ yield (Table 3, Entry 18$) .{ }^{1} \mathrm{H}$ NMR $\left(\mathrm{CDCl}_{3}, 300\right.$ MHz): 7.65 (d, $J=8.1 \mathrm{~Hz}, 2 \mathrm{H}), 7.28$ (d, $J=7.8 \mathrm{~Hz}, 2 \mathrm{H}), 5.92(\mathrm{~s}, 1 \mathrm{H}), 4.26$ (d, $J=16.5 \mathrm{~Hz}, 1 \mathrm{H})$, 3.92-3.99 (dd, $J=16.2 \mathrm{~Hz}$ and $J=3.3 \mathrm{~Hz}, 2 \mathrm{H}), 3.08(\mathrm{~m}, 1 \mathrm{H}), 2.51(\mathrm{~m}, 2 \mathrm{H}), 2.37$ (s, 3H), 1.99 (dd, $J=17 \mathrm{~Hz}$ and $J=3.3 \mathrm{~Hz}, 1 \mathrm{H}$ ) ppm.

\section{Acknowledgements}

The authors are grateful to the Fundação para a Ciência e Tecnologia (POCI 2010) and FEDER for financial support (ref. SFRH/BPD/18740/2004, SFRH/BD/30619/2006 and POCI/QUI/56582/2004). 


\section{References and Notes}

1. Khand, I. U.; Knox, G. R.; Pauson, P. L.; Watts, W. E.; Foreman, M. I., J. Chem. Soc., Perkin Trans. 1 1973, 977.

2. (a) Gibson, S. E.; Mainolfi, N. Angew. Chem. Int. Ed. 2005, 44, 3022. (b) Gibson, S. E.; Stevenazzi, A. Angew. Chem. Int. Ed. 2003, 42, 1800. (c) Brummond, K. M.; Kent, J. L., Tetrahedron 2000, 56, 3263. (d) Fruhauf, H.-W., Chem. Rev. 1997, 97, 523.

3. (a) Inagaki, F.; Mukai, C. Org. Lett. 2006, 8, 1217. (b) Kwong, F. Y.; Lee, H. W.; Qiu, L. Q.; Lam, W. H.; Li, Y. M.; Kwong, H. L.; Chan, A. S. C. Adv. Synth. Catal. 2005, 347, 1750. (c) Wender, P. A.; Croatt, M. P.; Deschamps, N. M. Angew. Chem. Int. Ed. 2006, 45, 2459.

4. Tang, Y. F.; Deng, L. J.; Zhang, Y. D.; Dong, G. B.; Chen, J. H.; Yang, Z. Org. Lett. 2005, 7, 593.

5. Tang, Y. F; Deng, L. J.; Zhang, Y. D.; Dong, G. B.; Chen, J. H.; Yang, Z. Org. Lett. 2005, 7, 1657.

6. Rios, R.; Paredes, S.; Pericàs, M. A.; Moyano, A. J. Organomet. Chem. 2005, 690, 358.

7. Rios, R.; Rivero, M. R.; Carretero, J. C. Org. Lett. 2005, 7, 431.

8. (a) Gupta, A. K.; Park, D. I.; Oh, C. H., Tetrahedron Lett. 2005, 46, 4171. (b) Gupta, A. K.; Park, D. I.; Oh, C. H. Tetrahedron Lett. 2005, 46, 5097.

9. Datta, S.; Liu, R.-S. Tetrahedron Lett. 2005, 46, 7985.

10. (a) Hotha, S.; Maurya, S. K.; Gurjar, M. K. Tetrahedron Lett. 2005, 46, 5329. (b) James, P.; Felpin, F. X.; Landais, Y.; Schenk, K. J. Org. Chem. 2005, 70, 7985. (c) Winkler, J. D.; Lee, E. C. Y.; Nevels, L. I. Org. Lett. 2005, 7, 1489.

11. Brummond, K. M.; Curran, D. P.; Mitasev, B.; Fischer, S. J. Org. Chem. 2005, 70, 1745.

12. Cao, H.; Van Ornum, S. G.; Deschamps, J.; Flippen-Anderson, J.; Laib, F.; Cook, J. M. J. Am. Chem. Soc. 2005, 127, 933.

13. Mukai, C.; Uchiyama, M.; Hanaoka M. J. Chem. Soc., Chem. Commun. 1992, 1014.

14. Jeong, N.; Lee, S. J. Tetrahedron Lett. 1993, 34, 4027.

15. (a) Kent, J. L.; Wan, H.; Brummond, K. M. Tetrahedron Lett. 1995, 36, 2407. (b) Brummond, K. M.; Wan, H.; Kent, J. L. J. Org. Chem. 1998, 63, 6535.

16. (a) Brummond, K. M.; Wan, H. Tetrahedron Lett. 1998, 39, 931. (b) Brummond, K. M.; Lu, J., J. Am. Chem. Soc. 1999, 121, 5087. (c) Brummond, K. M.; Mitasev, B. Org. Lett. 2004, $6,2245$.

17. (a) Saito, T.; Shiotani, M.; Otani, T.; Hasaba, S. Heterocycles 2003, 60, 1045. (b) Yu, C. M.; Hong, Y. T.; Lee, J. H. J. Org. Chem. 2004, 69, 8506. Yu, C. M.; Hong, Y. T.; Yoon, S. K.; Lee, J. H. Synlett 2004, 1695.

18. (a) Cao, H.; Van Ornum, S. G.; Cook, J. M. Tetrahedron Lett. 2000, 41, 5313. (b) Cao, H.; Flippen-Anderson, J.; Cook, J. M. J. Am. Chem. Soc. 2003, 125, 3230.

19. Van Ornum, S. G.; Bruendl, M. M.; Cao, H.; Reddy, M.; Grubisha, D. S.; Bennett, D. W.; Cook, J. M. J. Org. Chem. 2000, 65, 1957. 
20. Brummond, K. M.; Kerekes, A. D.; Wan, H. J. Org. Chem. 2002, 67, 5156.

21. (a) Rutherford, D. T.; Christie, S. D. R. Tetrahedron Lett. 1998, 39, 9805. (b) Rios, R.; Pericas, M. A.; Moyano, A.; Maestro, M. A.; Mahia, J. Org. Lett. 2002, 4, 1205.

22. Chung, Y. K. Coord. Chem. Rev. 1999, 188, 297.

23. Jordi, L.; Segundo, A.; Camps, F.; Ricart, S.; Moretó, J. M. Organometallics 1993, 12, 3795.

24. Sugihara, T.; Yamaguchi, M. Synlett 1998, 1384.

25. Hayashi, M.; Hashimoto, Y.; Yamamoto, Y.; Usuki, J.; Saigo, K. Angew. Chem. Int. Ed. 2000, 39, 631 .

26. Baghlaf, A. O.; Ishaq, M.; Daifuliah, A. S. Polyhedron 1984, 3, 235.

27. Billington, D. C.; Helps, I. M.; Pauson, P. L.; Thomson, W.; Willison, D. J. Organomet. Chem. 1988, 354, 233.

28. Chandras, L; Rodley, G. A. Inorg. Chem. 1965, 4, 1360.

29. Goettmann, F.; Le Floch, P.; Sanchez, C. Chem. Commun. 2006, 180.

30. McDonald, F. E.; Schultz, C. C. J. Am. Chem. Soc. 1994, 116, 9363.

31. (a) Mook, Jr., R.; Sher, P. M. Org. Synth. Coll Vol. 8, p 381. (b) Hoye, T. R.; Suriano, J. A. Organometallics 1992, 11, 2044.

32. Jeong, N.; Sung, B. K.; Choi, Y. K. J. Am. Chem. Soc. 2000, 122, 6771.

33. (a) Billington, D. C.; Willison, D. Tetrahedron Lett. 1984, 25, 4041. (b) Brandsma, L.; Verkruijsse, H. D. Synthesis of Acetylenes, Allenes and Cumulenes; Elsevier: Amsterdam, $1981 ;$ p 231.

34. Ji, J.; Wang, Z.; Lu, X. Organometallics 1996, 15, 2821.

35. (a) Patel, M. C.; Livinghouse, T.; Pagenkopf, B. L. Org. Synth., Vol. 80, p 93. (b) Pagenkopf, B. L. Livinghouse, T. J. Am. Chem. Soc. 1996, 118, 2285.

36. Gibson, S. E.; Johnstone, C.; Loch, J. A.; Steed, J. W.; Stevenazzi, A. Organometallics 2003, 22, 5374 